\title{
Ground-Water Studies in Fairbanks, Alaska- A Better Understanding of Some of the United States' Highest Natural Arsenic Concentrations
}

\begin{abstract}
he U.S. Geological Survey (USGS), in conjunction with the University of Colorado, University of Alaska-Fairbanks (UAF), and Fairbanks Gold Mining Inc. (FGMI), is investigating the occurrence and distribution of arsenic and other dissolved metal species in the ground water of Fairbanks, Alaska. Major-, minor-, and trace-element concentrations in ground water have been determined using a variety of analytical techniques. Using these data, scientists can

- $\quad$ Assess the spatial distribution of ground water that has high levels of arsenic and other potentially harmful metals

- $\quad$ Provide information about the natural background concentration of arsenic and other elements in ground water in Fairbanks

- Determine the source and controls on the concentration of arsenic in the ground water
\end{abstract}

\section{Geologic/Hydrologic Setting}

The bedrock geology of much of Fairbanks is made up of metamorphosed quartzite, schist, and slate of late Precambrian and Paleozoic age. The upland areas, however, are underlain by Cretaceous granites, which have intruded these metamorphic rocks. Formation of gold deposits occurred simultaneously with emplacement of the granites, as evidenced by gold and related metals found in quartz veins and disseminated in both the metamorphic and the igneous rocks. Areas within and surrounding Fairbanks have been mined for both this lode gold, and downstream placer gold, since the early 1900's. Within the metamorphic rocks, the dominant minerals associated with gold are arsenopyrite (ironarsenic sulfide), stibnite (antimony sulfide), and pyrite (iron sulfide).

The ground-water hydrology in the Fairbanks area consists of a network of fractures, faults, and folds that allow rain and snow melt to infiltrate the rocks and enter the local aquifer system. The presence of high $(>1 \mathrm{mg} / \mathrm{L}$ (milligram per liter)) amounts of arsenic in ground-water samples was first reported in the mid 1970's by researchers with UAF. This discovery prompted additional studies in the late 1970's and early 1980's by the Center for Disease Control,

Fairbanks and Ester areas showing well locations for the 1999-2000 study (•) and the 2000-2001 study (o).
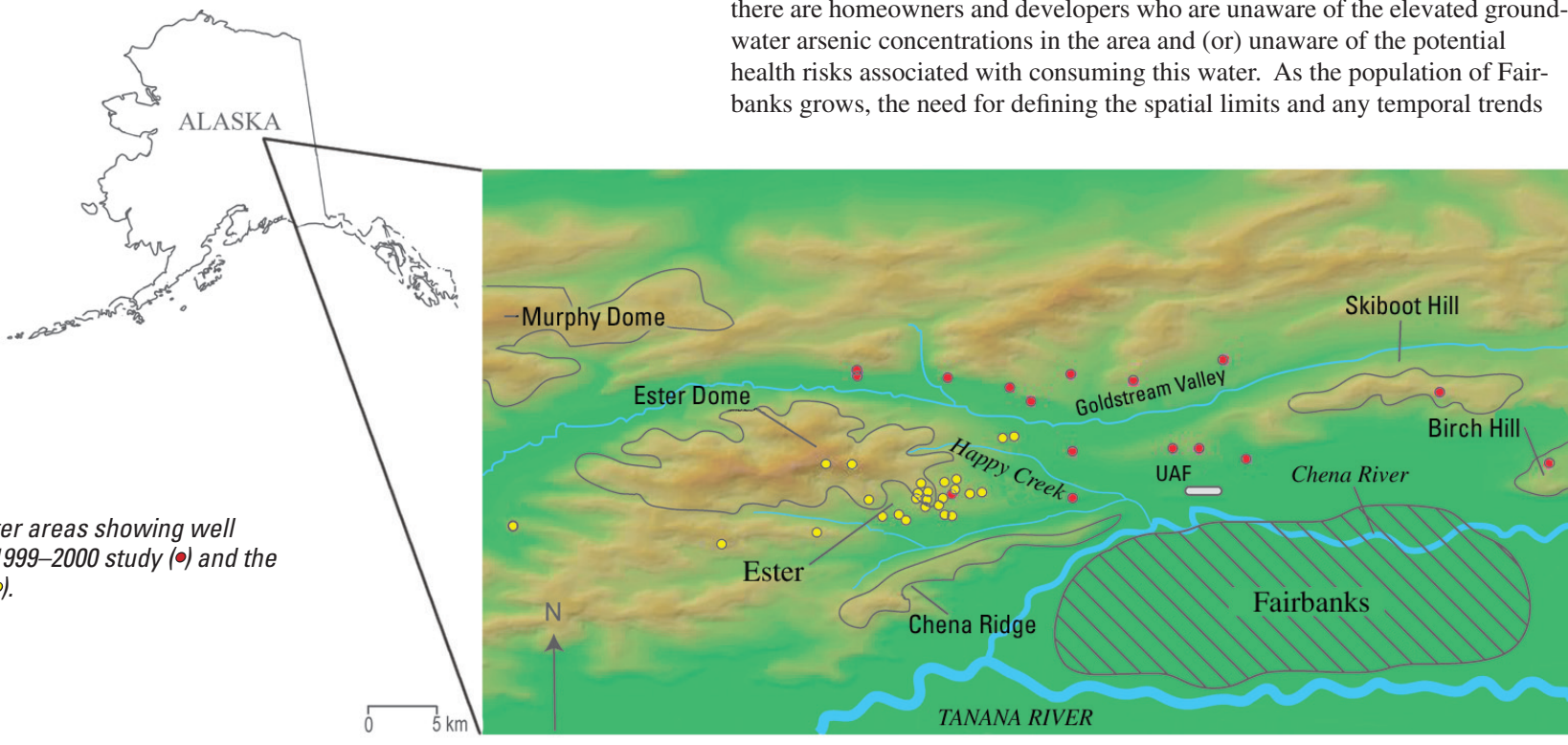

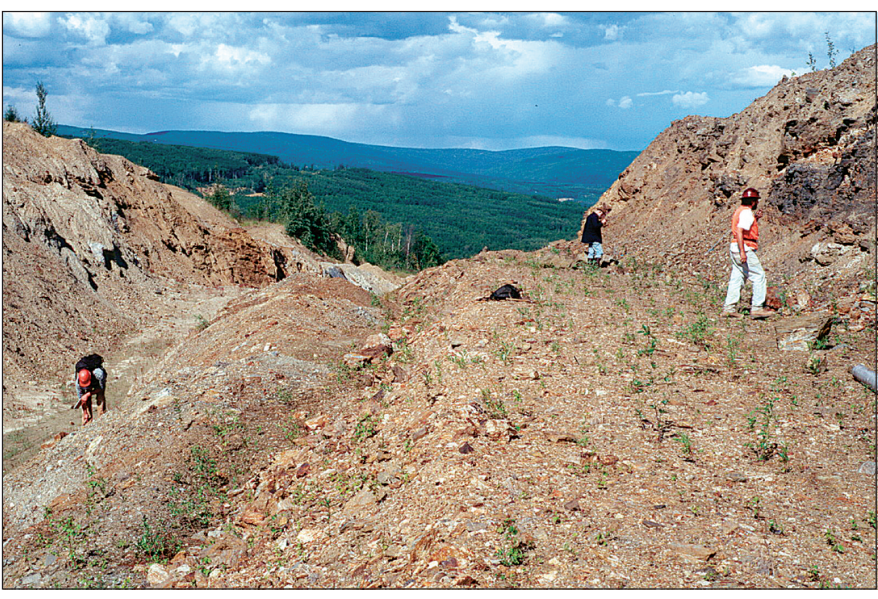

U.S. Geological Survey geologists explore a mineralized shear zone at the Ryan Lode property while collecting rock samples to learn more about the sources of arsenic in the ground water.

UAF, and USGS. These studies determined that water in many domestic wells contained as much as $1-10 \mathrm{mg} / \mathrm{L}$ dissolved arsenic, among the highest concentrations reported for natural water anywhere in the United States. The wells tested in these previous studies were located throughout the Goldstream Valley and Ester Dome parts of the city. In addition, individuals who were exposed to high-arsenic water had elevated arsenic concentrations in their urine, hair, and nails, although no specific health problems were identified.

\section{Environmental Concerns}

Fairbanks is the second largest population center in the State of Alaska. The majority of homes outside Fairbanks proper rely on wells or water storage tanks for their domestic water needs. Many homeowners have installed systems that remove or at least reduce the arsenic concentration via distillation, reverse osmosis, or activated alumina; however, it is conceivable that there are homeowners and developers who are unaware of the elevated groundwater arsenic concentrations in the area and (or) unaware of the potential health risks associated with consuming this water. As the population of Fairbanks grows, the need for defining the spatial limits and any temporal trends 


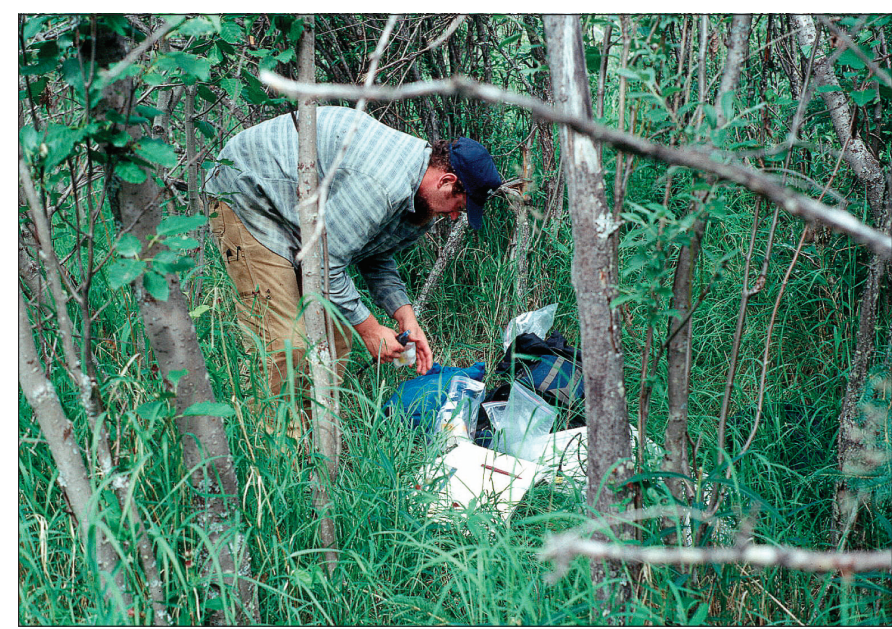

U.S. Geological Survey geologist conducting a surface water sampling during summer 2001.

of unsafe drinking water will increase. Furthermore, since the recent recommendation by the National Research Council that the Maximum Contaminant Level (MCL) of 50 micrograms per liter $(\mu \mathrm{g} / \mathrm{L})$ be lowered due to the risk of developing bladder and other cancers, the number of domestic wells exceeding the MCL will markedly increase. Homeowners and developers, in Fairbanks, Ester, and surrounding areas, will be faced with the need to better understand both controls on arsenic mobility and distribution, and the health implications associated with elevated abundances of arsenic and related elements in the local ground water.

\section{Field Investigation}

Ground-water samples were collected seasonally during 1999-2000 from seventeen residential wells in the Fairbanks and Ester areas (location map). Owing to complications associated with getting water directly from the residential wells at the well head, most samples were taken at the base of the pressure tank located within the homes. During the sampling, water $\mathrm{pH}$, specific conductance (SC), temperature (T), and dissolved oxygen were measured at 10-minute intervals for 30 minutes. Collected samples were analyzed for major-, minor-, and trace-element chemistry. Additional determinations were performed on samples for arsenic and iron species. Wells were sampled at roughly 2-month intervals for the course of 1 year. During 2000-2001, similar studies were carried out using a total of 29 monitoring and residential wells and three streams on Ester Dome, the second area near Fairbanks characterized by the anomalous arsenic (location map).

\section{Arsenic Concentrations in Ground Water}

Water quality data collected from the wells in the Goldstream Valley and Ester Dome areas reveal that arsenic concentrations can range from below detection $(<3 \mu \mathrm{g} / \mathrm{L})$ to $1,670 \mu \mathrm{g} / \mathrm{L}$, which is approximately 30 times the current MCL. The extreme variations in concentration may occur in wells a few hundred meters apart, many of which may be drawing from the same aquifer. Many of the other geochemical parameters measured in these studies also show a similarly wide variation, such as specific conductance ((SC) 55-1,970 microsiemens per centimeter $(\mu \mathrm{S} / \mathrm{cm})$ ), calcium ((Ca) $0.6-280 \mathrm{mg} / \mathrm{L})$, and manganese ((Mn) 0.02-5,600 $\mu \mathrm{g} / \mathrm{L}))$ (table 1). Despite the wide range in absolute geochemical parameters, ground water throughout the area does show many similar characteristics. The $\mathrm{pH}$ of the ground water is consistently neutral (6.0 to 7.86 standard $\mathrm{pH}$ units); the major elements and anions decrease in concentration in the following order: calcium $(\mathrm{Ca})>$ magnesium $(\mathrm{Mg})>$ sodium $(\mathrm{Na})>$ potassium $(\mathrm{K})$ and bicarbonate $\left(\mathrm{HCO}_{3}{ }^{-}\right)>$sulfate $\left(\mathrm{SO}_{4}{ }^{2-}\right)>$ nitrate $\left(\mathrm{NO}_{3}^{-}\right)>$chlorine $\left(\mathrm{Cl}^{-}\right)>$fluorine $\left(\mathrm{F}^{-}\right)$. The major difference between the samples with high and low arsenic concentrations is the occurrence of elevated levels of one or more of the following minor elements in conjunction with high arsenic: iron $(\mathrm{Fe})$, manganese $(\mathrm{Mn})$, antimony $(\mathrm{Sb})$, and to a lesser extent barium $(\mathrm{Ba})$ and phosphorus $(\mathrm{P})$.

We have determined that the high arsenic most likely results both from ground water coming into contact with areas that have a high concentration of arsenic-bearing sulfide minerals, such as arsenopyrite, pyrite, and stibnite, and from arsenic being remobilized from iron- and manganese-oxides that
Table 1. Concentration values of unfiltered samples from both the 1999-2000 and 2000-2001 studies.

[Values indicate maximum and minimum values detected. Values with stars indicate the lower detection limit for that analytical technique]

\begin{tabular}{|c|c|c|}
\hline $\begin{array}{c}\mathbf{p H} \\
\mathrm{SC}(\mu \mathrm{S} / \mathrm{cm})\end{array}$ & $\begin{array}{c}\text { MAX } \\
7.86 \\
1970\end{array}$ & $\begin{array}{c}\text { MIN } \\
6.00 \\
55\end{array}$ \\
\hline \multicolumn{3}{|l|}{$m g / L$} \\
\hline $\operatorname{ALK}\left(\mathrm{HCO}_{3}{ }^{-}\right)$ & 791 & 0.1 \\
\hline Ca & 280 & 0.06 \\
\hline Mg & 91 & 0.04 \\
\hline $\mathrm{Na}$ & 303 & 2.09 \\
\hline $\mathbf{K}$ & 78.8 & 0.05 \\
\hline $\mathrm{SO}_{4}{ }^{2-}$ & 300 & 1.00 \\
\hline $\mathbf{F}^{-}$ & 1.6 & 0.1 \\
\hline $\mathrm{Cl}^{-}$ & 91 & 0.21 \\
\hline $\mathrm{NO}_{3}^{-}$ & 180 & 0.08 \\
\hline $\mathrm{SiO}_{2}$ & 87.7 & 3.90 \\
\hline Al & 16 & $0.01 *$ \\
\hline $\mathbf{F e}$ & 74 & $0.05^{*}$ \\
\hline \multicolumn{3}{|l|}{$\mu g / L$} \\
\hline As & 1670 & $3 *$ \\
\hline $\mathbf{B a}$ & 280 & $0.3 *$ \\
\hline Mn & 5900 & $0.3^{*}$ \\
\hline $\mathbf{P}$ & 1000 & $5 *$ \\
\hline $\mathbf{Z n}$ & 7200 & $0.05^{*}$ \\
\hline $\mathbf{C u}$ & 310 & $0.5^{*}$ \\
\hline $\mathbf{P b}$ & 120 & $0.05^{*}$ \\
\hline $\mathbf{N i}$ & 48 & $0.1^{*}$ \\
\hline Co & 32 & $0.02 *$ \\
\hline $\mathrm{Cr}$ & 20 & $1 *$ \\
\hline Мo & 10.7 & $0.2 *$ \\
\hline $\mathbf{S b}$ & 59.3 & $0.1 *$ \\
\hline $\mathbf{W}$ & 0.82 & $0.02 *$ \\
\hline $\mathbf{U}$ & 37.3 & $0.005^{*}$ \\
\hline
\end{tabular}

formed during weathering of these primary sulfide minerals. The sulfide minerals were originally localized in the rocks in Goldstream Valley and Ester Dome during the Cretaceous goldforming event. Laboratory studies indicate that the inorganic arsenic in the ground water is present in two of the more common oxidation states, as arsenite (As(III)) and arsenate $(\mathrm{As}(\mathrm{V}))$. These laboratory results correlate well with the dissolved oxygen data collected in the field, which indicate a range of dissolved oxygen concentrations in the ground water from strongly reducing $(<0.1 \mathrm{mg} / \mathrm{L})$, associated with the occurrence of As(III), to oxidizing (>8 mg/L), associated with the occurrence of As(V). A large change in arsenic concentrations over the course of a year is not apparent, suggesting that the ground water in this area has a long residence time from when it enters the aquifer until it is pumped by domestic users.

The spatial variation in ground-water arsenic concentration may be related to the complex geologic structure of the Fairbanks area. Some of the ground water with high arsenic is distant from any known mineralized areas. Therefore it is possible that the abundant faults and shear zones mapped in the Fairbanks area serve as flow paths in the aquifer.

\section{Implications of Research}

The results of this study show that elevated natural arsenic concentrations in ground water associated with local gold mineralization are significant. The levels of arsenic and antimony exceed primary drinking water standards, while iron levels exceed secondary drinking water standards. Knowledge of the naturally high background concentration of arsenic in the ground water is crucial for determining the placement of future wells in the upland areas of Fairbanks and elsewhere in interior Alaska. Studies continue in order to better understand how naturally occurring arsenic enters the ground water-and how it can be removed. The complex relationship between the structural geology and the ground-water chemistry in this area of poor rock surface exposures is critical for defining arsenic dispersion in the subsurface. In addition, the high background levels for arsenic in Fairbanks ground water provide a natural laboratory in which scientists can develop a better understanding of arsenic mobility in subsurface environments.

\section{For more information contact:}

$\begin{array}{ll}\text { Seth Mueller } & \text { Philip Verplanck } \\ \text { U.S. Geological Survey } & \text { U.S. Geological Survey } \\ \text { MS 973, Denver Federal Center } & \text { 3215 Marine St. } \\ \text { Denver, CO 80225-0046 } & \text { Boulder, CO 80303 } \\ \text { phone: 303-236-1882 } & \text { phone: 303-541-3080 } \\ \text { email: shmuelle@usgs.gov } & \text { email: plv@usgs.gov }\end{array}$

Rich Goldfarb

U.S. Geological Survey

MS 964, Denver Federal Center

Denver, CO 80225-0046

phone: 303-236-2441

email: goldfarb@usgs.gov 